\title{
Electrochemical Degradation of Reactive Orange 16 by using Charcoal-Based Metallic Composite Electrodes
}

(Penguraian Elektrokimia Reaktif Oren 16 Menggunakan Elektrod Komposit Logam Berasaskan Arang)

\author{
Zuhailie ZaKaria, Mohamed RoZali Othman, Siti Zubaidah Hasan* \& WAN YaAcob Wan AhMad
}

\begin{abstract}
The performance of charcoal composite electrodes, by using commercial activated charcoal and charcoals from coconut trunk, mangrove wood, rubber wood, and sugarcane, was compared in an attempt to fabricate effective and low cost electrodes for wastewater treatment in textile industries. Reactive Orange 16 was chosen as a model dye because of its high resistance towards conventional treatment methods, while sodium chloride was selected as a supporting electrolyte. The electrode efficiencies were determined based on the percentage of Reactive Orange 16 decolourisation. The charcoals used, duration of electrolysis, functional groups present in charcoals, Brunauer-Emmett-Teller surface area and production of hypochlorite ion that contribute to the effectiveness of the electrodes were examined. The coconut trunk, rubber wood, sugarcane, mangrove wood, and commercially available activated charcoals that were incorporated into tin composite electrodes were able to degrade Reactive Orange 16 until 98.5\%, 96.2\%, 83.0\%, 71.2\%, and 29.6\%, respectively, after 20 min of electrolysis. The degradation increases with duration of electrolysis. This study illustrated that the production of hypochlorite ion from sodium chloride in solution was the main factor that enhanced the Reactive Orange 16 colour removal. Adsorption process on the electrode surface did not play any significant role in the dye decolourisation.
\end{abstract}

Keywords: Agricultural waste; composite; decolourisation; electrolysis; reactive orange 16

\section{ABSTRAK}

Prestasi elektrod komposit berasaskan arang dengan menggunakan arang teraktif komersial dan arang daripada batang kelapa, kayu bakau, kayu getah dan tebu telah dibandingkan dalam satu percubaan untuk menghasilkan elektrod yang berkesan dan berkos rendah bagi perawatan air sisa industri tekstil. Reaktif Oren 16 dipilih sebagai pewarna ujian kerana ketahanannya yang tinggi terhadap kaedah perawatan konvensional manakala natrium klorida dipilih sebagai elektrolit penyokong. Keberkesanan elektrod ditentukan berdasarkan peratus penyahwarnaan Reaktif Oren 16. Jenis arang yang digunakan, tempoh masa elektrolisis, kumpulan berfungsi yang wujud dalam arang, luas permukaan BrunauerEmmett-Teller dan penghasilan ion hipoklorit yang menyumbang kepada keberkesanan elektrod tersebut telah dikaji. Arang daripada batang kelapa, kayu getah, tebu, kayu bakau, dan arang teraktif komersial yang dicampurkan dalam elektrod komposit tin mampu menguraikan Reaktif Oren 16 masing-masing sehingga 98.5\%, 96.2\% 83.0\%, $71.2 \%$ dan $29.6 \%$ selepas 20 min elektrolisis. Penguraian ini meningkat dengan pemanjangan tempoh masa elektrolisis. Hasil kajian menunjukkan bahawa penghasilan ion hipoklorit daripada larutan natrium klorida merupakan faktor utama yang menyebabkan peningkatan dalam penyahwarnaan Reaktif Oren 16. Proses penjerapan pada permukaan elektrod tidak memainkan peranan penting dalam penyahwarnaan pewarna yang digunakan.

Kata kunci: Elektrolisis; komposit; penyahwarnaan; reaktif oren 16; sisa pertanian

\section{INTRODUCTION}

The Malaysian batik industry has been long established and is one of the important branches of the textile industry in Malaysia. The industry uses lots of water in the textile dyeing processes thus, leaves a great amount of effluents to be treated. This is because the effluents are toxic, mutagenic, have low ability to biodegrade, high COD value, pH and temperature (Liakou et al. 1997; Šíma \& Hasal 2013). One of the most vivid indicators of textile industrial wastewater pollution is colour (Nigam et al. 1996). At very low dye concentrations, their strong colour are still visible and disturb the solubility of gas in water bodies (Chung
\& Stevens 1993). The highly coloured effluents can give severe problems when disposing and discharging the wastewater into the water system without proper treatment; hence this will cause serious problems to the environment (Zollinger 2003). The strong colour is caused by the unfixed dyes. The types of dye, fibre, mode of application and shade depth will affect the degree of dye fixation into fabric (Alvares et al. 2001). About 10,000 different dyes and pigments are produced annually (Doble \& Kumar 2005). The most common commercial dyes used in the textile industry are azo dyes, which are characterized by the presence of nitrogen-nitrogen double bonds $(\mathrm{N}=\mathrm{N})($ Lee et 
al. 2006). Almost $50 \%$ of produced dyes contain azo group (Bauer et al. 2001). Azo dyes, which normally consist of aromatic hydrocarbons, derivatives of benzene, aniline, toluene, naphthalene and phenol, are the most toxic to aquatic organisms. They pose lethal effect, carcinogenicity, genotoxicity and mutagenicity to fish, algae, bacteria as well as animals (Puvaneswari et al. 2006). Besides, the azo dyes are able to decrease the penetration of light, creating interruption in photochemical activities in aquatic systems (Sharma et al. 2003). Dyes are bright coloured (orange and yellow) because of chromosphere and azo group (Lee et al. 2006). The most problematic dye to be treated is reactive, water soluble, acidic and brightly coloured. These kinds of dye cannot be treated by conventional treatment methods (Willmott 1998). The complexity of aromatic molecular structure of the dyes may affect the stability and biodegradability of compounds (Wang \& Li 2007). C.I. Reactive Orange 16 (RO16), an anionic sulphonated reactive azo dye was chosen as the model dye because of its high resistance towards conventional treatment methods and difficult to biodegrade (Chen 2009). Other than dyes, effluent from batik industrial wastewater also consists of resin, wax and silicate (Rashidi et al. 2012).

A study to determine the best method, in terms of efficiency, easiness and cost saving procedure to treat textile wastewater, has been carried out by many researchers. Generally, wastewater treatment methods can be divided into three main categories, which are mainly biological, chemical and physical processes with their own advantages and disadvantages (Robinson et al.2001). As an example, although ozonation is useful to quickly degrade dye, it is a very expensive method (Tizaoui \& Grima 2011; Xu et al. 1999). Biological treatment is inefficient for azo compound degradation because of the large degree of aromatic groups present in the dye molecule. Under anaerobic and aerobic conditions, azo compounds are non-biodegradable. However, they are able to be degraded by Phanerochaete chrysosporium (Paszczynski \& Crawford 1995; Saxe et al. 2006). Chemical and physical techniques can be used to remove dye, but are limited only to small effluent volume (Robinson et al. 2001). The most interesting method to treat wastewater is by using electrochemical technology methods, which include electrooxidation, electrocoagulation, electrodeposition and electroflotation (Chen 2004). However, this paper is focused on the electrochemical oxidation technique which is proven to be a very effective method in textile wastewater treatment. The technique is able to completely oxidize organic pollutants to water and carbon dioxide (Parsa et al. 2009). Electron is the main reagent utilised in electrochemical technologies and it is called as 'clean reagent' (Maljaei et al. 2009). The risk of volatilization and releasing untreated residues could be minimized because electrolysis is conducted at atmospheric pressure and room temperature. During electrolysis, there were no consumption of additional reagents and no by-product or sludge was produced (Andrade et al. 2009). Furthermore, only a low consumption of energy is needed to degrade chromophore groups present in dyes from textile wastewater for a short period of electrolysis and the electricity cost is equivalent to the chemicals prices (Chatzisymeon et al. 2006; Robinson et al. 2001). Moreover, this method is safe for the environment as the breakdown of metabolites were mostly harmless. Hence, the treated wastewater can be released back into the nature and can also be efficiently reused for colouring application (Mohan et al. 2007; Ogutveren \& Koparal 1994; Pelegrini et al. 1999).

The electrode material selections are very important to obtain the desired result in the electrochemical oxidation process. In this study, charcoal was used as the main ingredient in electrode fabrication. It is known as a charcoal-based metallic composite electrode since metals are also used to increase colour removal efficiency. Five types of charcoal which are commercially available activated charcoal, coconut trunk, mangrove wood, rubber wood and sugarcane charcoals, are selected. Wood charcoal can be defined as a black porous solid that is made up of amorphous carbon and residual ash, cheap and can be obtained from burning wood (Abdollahi \& Hosseini 2014; Ahmedna et al. 2000). Application of wood charcoals in water treatment is not a new discovery. Activated charcoal from bamboo are utilized in wastewater treatment as adsorbents and can eliminate $\mathrm{Zn}$ (II) and $\mathrm{Ni}$ (II) efficiently from aqueous solution (Lalhruaitluanga et al. 2011). It was reported that carboxylic, hydroxyl and lactone groups present, for example, in coconut shell can cause sorption properties that have high affinity for metal ions and ensure heavy metal removal potential (Tan et al. 1993). Other report showed that polluting substances, such as arsenic, humic acid and phenol, can be removed by using activated carbon from rice husk and bagasse (Kalderis et al. 2008).

The objectives for this research were to fabricate low cost and environmental friendly charcoal-based metallic composite electrodes by using charcoals obtained from four different types of agricultural waste (rubber and mangrove woods, sugarcane and coconut trunk charcoals) and also commercially activated charcoals to study on factors that contribute to the RO16 dye degradation.

\section{MATERIALS AND METHODS}

\section{CHEMICALS, CHARCOAL AND DYESTUFF}

Deionized water was used as solvent throughout the experiment. A $200 \mathrm{mg} / \mathrm{L}$ of RO16 (C.I. 17757) as the chosen model dye and $1 \mathrm{M}$ of $\mathrm{NaCl}$ were prepared as stock solutions. The chemical structure of RO16 is as shown in Figure $1 . \mathrm{NaCl}$ and an activated charcoal powder were purchased from respective R\&M Chemicals and BDH Chemicals, and used without further purification. The working solution was prepared by adding $64 \mathrm{~mL}$ RO16 stock solution with $1 \mathrm{M} \mathrm{NaCl}$ to give $80 \mathrm{~mL}$ working solution, containing $160 \mathrm{mg} / \mathrm{L} \mathrm{RO} 16$ and $0.2 \mathrm{M} \mathrm{NaCl}$. Mangrove wood charcoal was bought from the local 
grocery store. Fresh rubber woods, coconut trunk as well as sugarcane were obtained from local villages. These three materials were openly burned to obtain charcoals and washed with water to get rid of ashes, dried overnight at $100^{\circ} \mathrm{C}$ (including mangrove wood charcoal), and ground (all four charcoals) to finely divided charcoal powder. All the five powdered charcoals were passed through a $45 \mu \mathrm{m}$ sieve. Powder graphite, tin, and polyvinyl chloride (PVC) were bought from Loba-Chemie, Riedel-de-Häen, and BDH Chemicals, respectively. Silver paint was purchased from RS Component and DEVCON epoxy-adhesive was bought from a local hardware store.

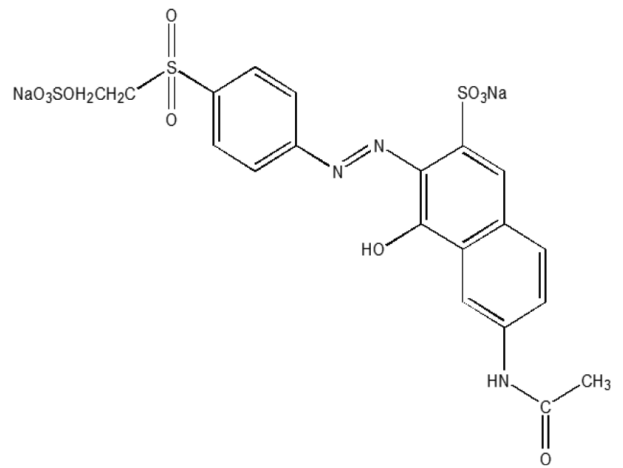

FIGURE 1. Structure molecule of Reactive Orange 16 (RO16)

\section{ELECTRODES PREPARATION}

The electrodes preparation was carried out according to the common procedure used elsewhere (Riyanto et al. 2007; Zakaria et al. 2015). The homogenized mixtures of charcoal-graphite-tin-PVC and graphite-PVC (by weight composition of $\mathrm{C}_{30} \mathrm{C}_{18}^{\mathrm{G}} \mathrm{Sn}_{12} \mathrm{PVC}_{40}$ and $\mathrm{C}_{60}^{\mathrm{G}} \mathrm{PVC}_{40}$ ) were placed in two different evaporating dishes. About $5 \mathrm{~mL}$ of THF was added and the mixtures were stirred by using a glass rod. This was to dissolve PVC in the mixture until the solvent evaporated to dryness. Then, the mixtures were oven dried at $100^{\circ} \mathrm{C}$ for $3 \mathrm{~h}$ and finely ground with a mortar and pestle. The two homogenized mixtures were added one after another into a $13-\mathrm{mm}$ diameter mould in $85: 15$ weight ratio and later pressed at 10 tonne $\mathrm{cm}^{-2}$ to form two-layer round-cylindrical pellets of approximately $0.8 \mathrm{~g}$. Then, the pellets were attached to the U-bent end of a silver wire at the centre of the round thin layer surface of the two-layer pellets by using silver paint. From observation, it was obvious the graphite layer was shinier as compared to the charcoal layer. The straight part of the silver wire was enclosed in glass tube. After the paint had dried, DEVCON epoxy-adhesive was applied all over the pellets, except for the front surface of the thick layer parts of the two-layer pellets. Then the modified pellet (at the surface where epoxy-adhesive was applied) was attached to a glass-slide $(22 \mathrm{~mm} \times 22 \mathrm{~mm})$ and the end of the glass tube to strengthen the fabricated electrode. This modification is to ensure that the fabricated electrode was completely closed to prevent the solution from coming in touch with the wire during the experiment (Zakaria et al. 2015).

\section{DECOLOURISATION OF REACTIVE ORANGE 16 DYE (RO16)}

The study on RO16 decolourisation was conducted at room temperature. A $100 \mathrm{~mL}$ Pyrex glass beaker was used as an electrolysis undivided cell. The five charcoal composite electrodes were used as anode while the stainless steel $\operatorname{rod}(\mathrm{d}=10 \mathrm{~mm})$ was used as cathode. The $80 \mathrm{~mL}$ working solution was stirred throughout the experiment by using a magnetic stirrer to ensure a uniform concentration and increase the mass transport of the electrolyte. Direct current power supply (TTi PSU Bench CPX400) was used as power supply at a fixed voltage of $10 \mathrm{~V}$ for $2 \mathrm{~h}$. The experimental set-up is as shown in Figure 2. About $3 \mathrm{~mL}$ of electrolytic solution was taken at every 10, 20, 40, 60, 90 , and 120 min for measuring absorbance by using a UVvisible spectrophotometer.

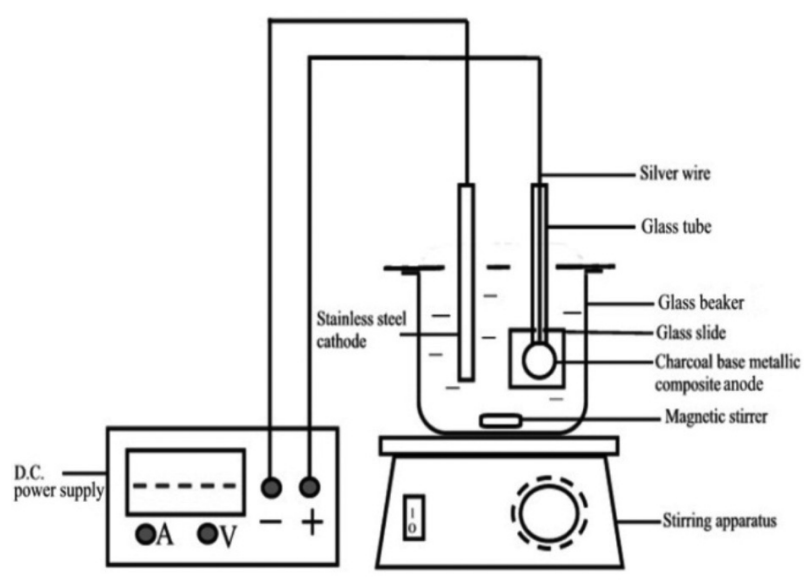

FIGURE 2. Experimental set-up for electrolysis process

\section{INSTRUMENTATION}

The decolourisation of RO16 was determined by the changes in absorption intensity of azo chromophore $(-\mathrm{N}=\mathrm{N}-)$ at a wavelength of $493 \mathrm{~nm}$ by using UV-visible spectrophotometer while Chemical Oxygen Demand (COD) was measured by using Hach spectrophotometer (DR/2400) according to Method 8000, as suggested by the DR/2400 Procedure Manual (Hach 2004). The electrode effectiveness was evaluated by the percentage of RO16 colour removal. This paper will focus on two RO16 absorption bands which were located at $388 \mathrm{~nm}$ (due to $\pi-\pi^{*}$ transition due to the aromatic rings bonded to the azo group) and $493 \mathrm{~nm}$ (due to chromophobic azo compound $n-\pi^{*}$ transitions). Both bands contributed to the strong orange colour appearance (Migliorini et al. 2011). The spectra of the charcoals were recorded by using Fourier Transform Infrared Spectrometer (FTIR) to identify the functional groups present in the charcoals, which may be responsible for decolourisation and COD removal efficiency. The Scanning Electron Microscope 
(SEM) was performed to observe porosity of the charcoals. The surface area of the charcoals was verified by using Brunauer-Emmett-Teller analysis (BET).

\section{RESULTS AND DISCUSSION}

The colour removal experiments were conducted for 2 $\mathrm{h}$ and the results obtained are as summarized in Table 1 as well as in Figures 3 and 4. As mentioned previously, the charcoals used in the composite electrodes were from coconut trunk, rubber wood, sugarcane, mangrove wood and the commercial charcoal. They were able to reduce RO16 colour up to $98.5 \%, 96.2 \%, 83.0 \%, 71.2 \%$ and $29.6 \%$, respectively, after 20 min of electrolysis and increased up to $99.8 \%, 99.0 \%, 99.5 \%, 99.2 \%$, and $83.3 \%$, respectively, after 2 h. In Figure 3, the UV-visible spectra showed that both maximum peaks at 388 and $493 \mathrm{~nm}$ decreased in absorbance, in tandem with the decrease in RO16 colour intensity. The decrease signifies the breakage of azo bonds $(\mathrm{N}=\mathrm{N})$ and degradation of aromatic rings (Migliorini et al. 2011). Rapid decrease of the two absorption bands can be observed with the coconut trunk charcoal composite electrode as it removed $75.2 \%$ and $98.5 \%$ of RO16 colour in 10 and 20 min, respectively. The efficiencies of rubber wood, sugarcane and mangrove wood charcoal composite electrodes in degrading azo chromophore were also proven since the two bands were almost vanished in respective 20,40 and $60 \mathrm{~min}$ of

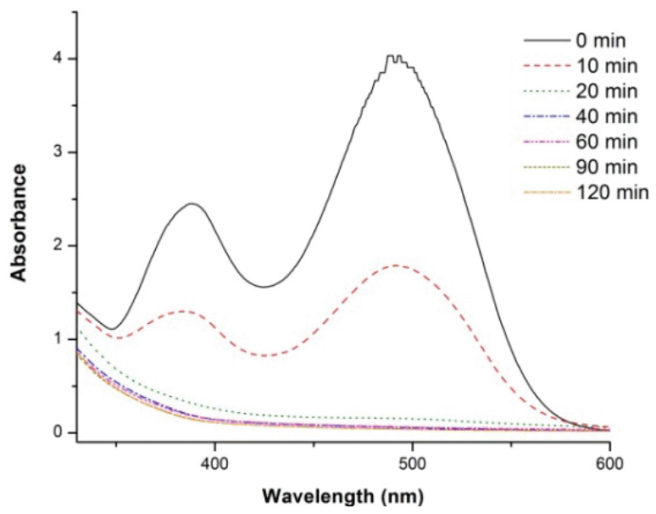

Rubber wood charcoal

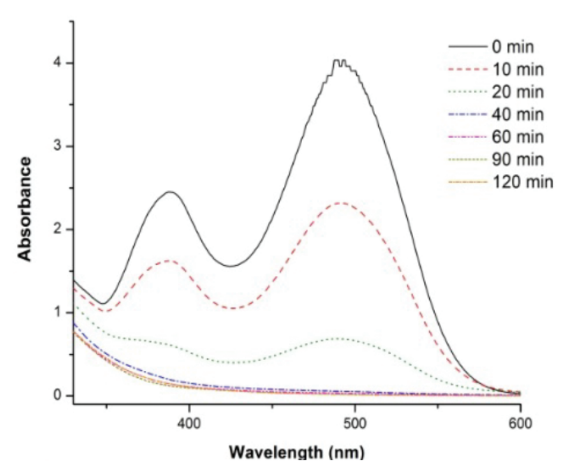

Sugercane charcoal

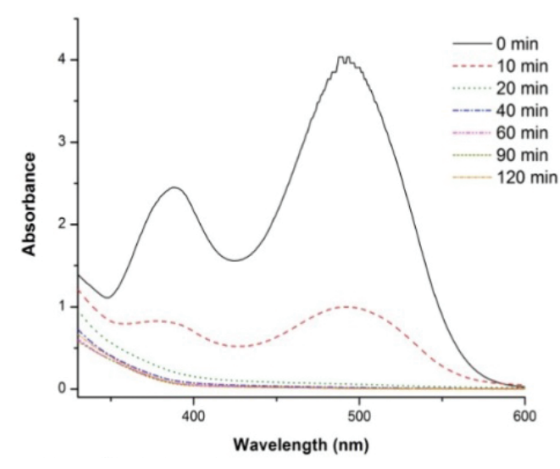

Coconut trunk charcoal

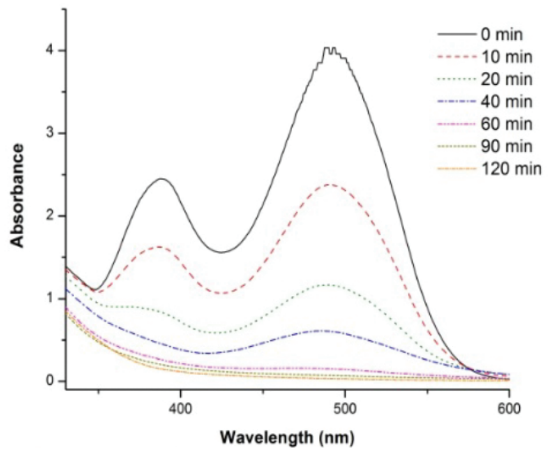

Mangrove wood charcoal

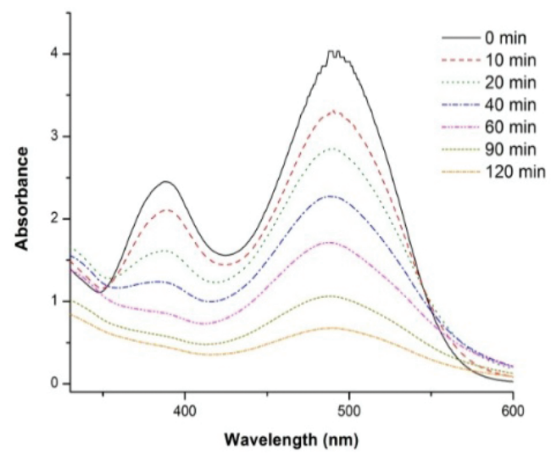

Commercial activated charcoal

FIGURE 3. UV-visible spectra of RO16 degradation by electrolysis using composite electrodes with different sources of charcoals 
electrolysis. However, the commercial activated charcoal composite electrode needed $120 \mathrm{~min}$ to degrade RO16 dye to $83.3 \%$. The percentages of colour removal increase proportionally with the duration of electrolysis.

Figure 4 shows the effects of decolourisation percentages against time for various charcoal composite electrodes. Generally, from five charcoal-based composite electrodes, four were effective in decolourising the RO16 textile dye. The coconut trunk charcoal composite electrode was the most efficient as compared to others while the commercial activated charcoal gave the lowest degradation efficiency since it took a longer time to degrade azo bonds in $\mathrm{RO} 16$.

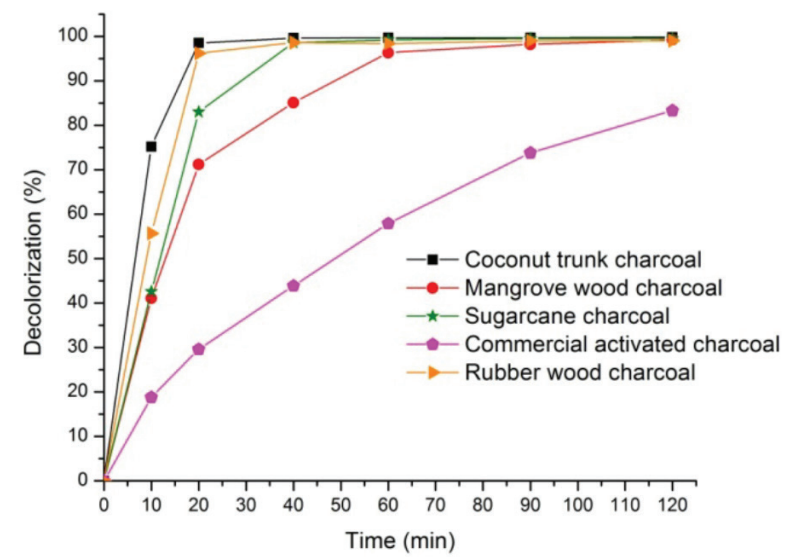

FIGURE 4. Effects of electrolysis time on decolorization percentages of RO16 using composite electrodes with different sources of charcoals

This study focused on charcoal as the main anode component for the oxidation process. Only one-layer charcoal-graphite-tin-PVC as anode fabricated electrode was used in the decolourisation of RO16 textile dyes. However, since the pellets contained charcoal as the main component, the resulting pellet became less dense; thus, allowing the solution to penetrate through where the silver wire cannot be attached to the pellets completely (Zakaria et al. 2015). Connection between silver wire and fabricated electrode are very important because silver wire acts as an electrical lead in the electrochemical set-up (Kartick et al. 2017).
Nevertheless, no connection is discovered between colour removal and COD removal (Rajkumar \& Kim 2006). According to the results obtained, as summarized in Table 1 and as shown in Figure 5, mangrove wood charcoal composite electrodes gave the highest COD removal percentage after $2 \mathrm{~h}$ of electrolysis $(56.4 \%)$, followed by charcoals of coconut trunk, commercially activated, sugarcane and rubber wood composite electrodes with $53.9 \%, 43.7 \%, 37.6 \%$, and $32.2 \%$ COD removal, respectively. Even though colour removal shown by the commercial activated charcoal composite electrode was the lowest, COD removal for this electrode was better than sugarcane and rubber wood charcoal composite electrodes. The capability of all charcoal composite electrodes in COD removal was not very efficient even though the colour removal rate was comparatively high, demonstrating that the breakage of the azo bonds was the first step of electrochemical degradation, followed by degradation of aromatic rings which led to the continuation of COD removal (Fernandes et al. 2004). All charcoal composite electrodes showed an increase in COD removal percentages against time, except for the sugarcane and rubber wood charcoal composite electrodes.

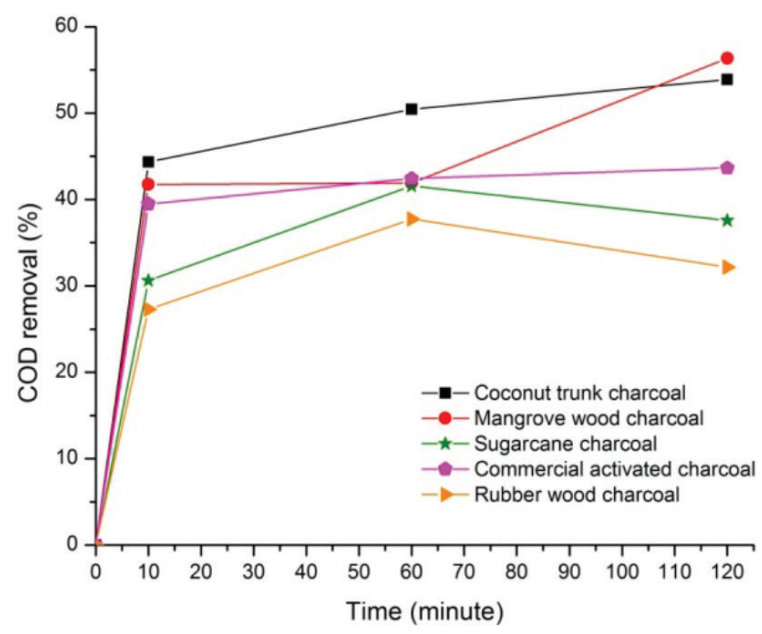

FIGURE 5. COD removal percentages of RO16 solution with time in electrolysis using composite electrodes with different sources of charcoals

TABLE 1. Percentage color and COD removal of RO16 by electrolysis using composite electrodes with different sources of charcoals

\begin{tabular}{ccccccccccc}
\hline $\begin{array}{c}\text { Electrolysis time } \\
(\mathrm{min})\end{array}$ & \multicolumn{3}{c}{ Coconut trunk } & \multicolumn{2}{c}{ Sugarcane } & \multicolumn{2}{c}{ Rubber wood } & \multicolumn{2}{c}{$\begin{array}{c}\text { Mangrove wood } \\
\text { Commercial } \\
\text { activated }\end{array}$} \\
\cline { 2 - 12 } & Color & COD & Color & COD & Color & COD & Color & COD & Color & COD \\
\hline 10 & 75.3 & 44.4 & 42.6 & 30.6 & 55.7 & 27.3 & 41.1 & 41.7 & 18.8 & 39.5 \\
20 & 98.5 & - & 83.0 & - & 96.2 & - & 71.2 & - & 29.6 & - \\
40 & 99.6 & - & 98.6 & - & 98.6 & - & 85.1 & - & 43.9 & - \\
60 & 99.7 & 50.4 & 99.2 & 41.6 & 98.4 & 37.7 & 96.3 & 41.9 & 57.9 & 42.4 \\
90 & 99.7 & - & 99.5 & - & 99.0 & - & 98.2 & - & 73.8 & - \\
120 & 99.8 & 53.9 & 99.5 & 37.6 & 99.0 & 32.2 & 99.2 & 56.4 & 83.3 & 43.7 \\
\hline
\end{tabular}


Anode material is one of the vital part of an anodic oxidation process (Chen 2004). SEM was utilized to study the topography of the charcoals, which give useful information on surface features (Achaw 2012). Figure 6 shows the SEM images of all raw charcoals used. The non-uniformity in sizes and shapes of the particles were observed. The porosity of charcoals enhanced the value of surface area; hence, increased the saturation capacity per unit mass of charcoals. To investigate the surface area of these charcoals, BET analysis was used.
Based on the BET studies, the commercial activated charcoal powder recorded the highest surface area (871.3), and followed by charcoals from coconut trunk (161.4), sugarcane (109.5), rubber wood (13.2) and mangrove wood $\left(2.0 \mathrm{~m}^{2} \mathrm{~g}^{-1}\right)$ (Table 2). The values of surface area of the charcoals may vary, depending on the sources of samples (Salehin et al. 2015). Although the commercial activated charcoal provides the highest surface area, the decolourisation rate of RO16 dye by using this electrode was the lowest.
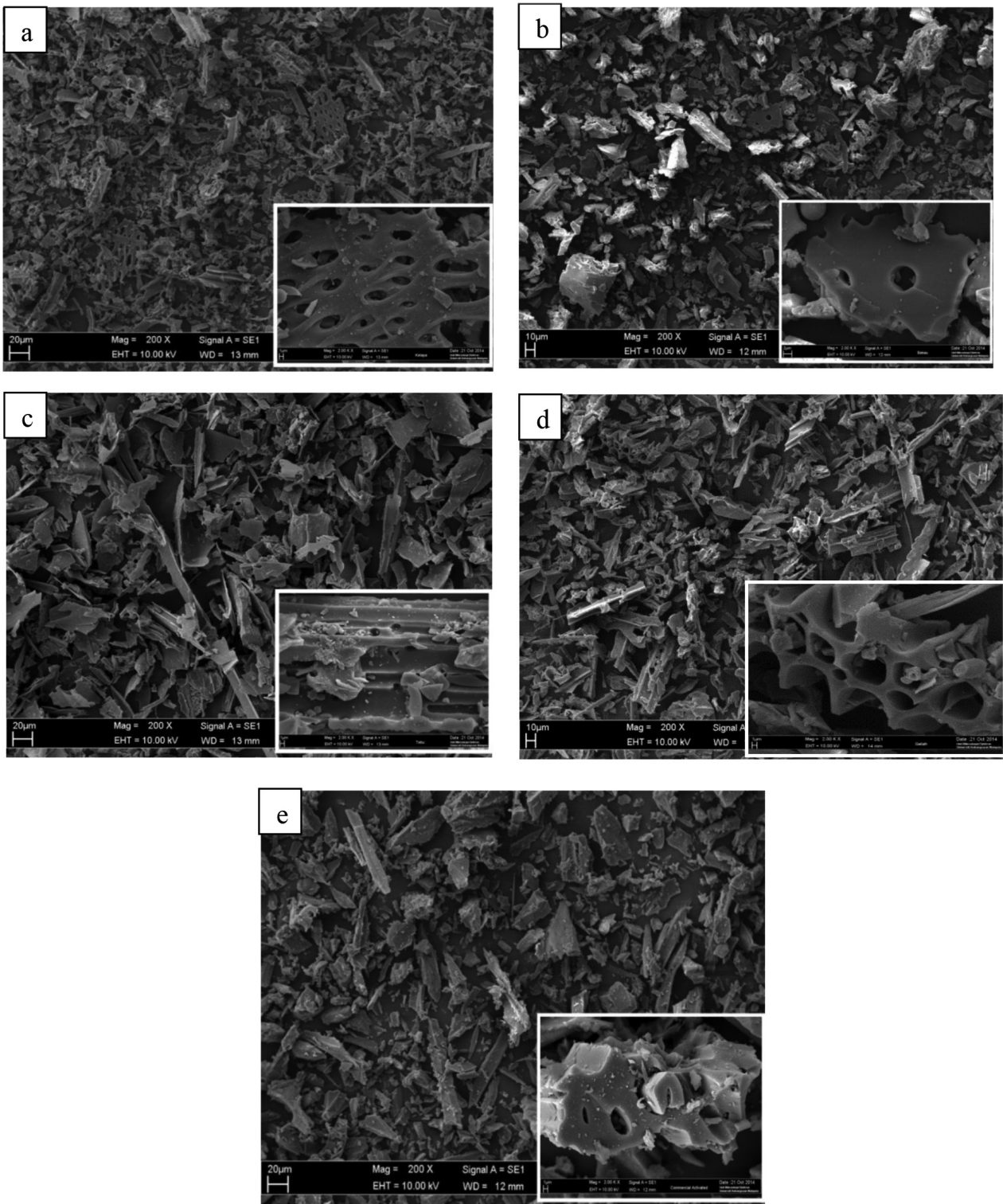

FIGURE 6. SEM images of charcoals powder from, a) coconut trunk b) mangrove wood c) sugarcane d) rubber wood and e) commercial activated charcoal

TABLE 2. BET surface area obtained from different sources of raw charcoals

\begin{tabular}{lccccc}
\hline Source of charcoal & $\begin{array}{c}\text { Coconut } \\
\text { trunk }\end{array}$ & $\begin{array}{c}\text { Rubber } \\
\text { wood }\end{array}$ & Sugarcane & $\begin{array}{c}\text { Mangrove } \\
\text { wood }\end{array}$ & $\begin{array}{c}\text { Commercial activated } \\
\text { charcoal }\end{array}$ \\
\hline Surface area $\left(\mathrm{m}^{2} \mathrm{~g}^{-1}\right)$ & 161.4 & 13.2 & 109.5 & 2.0 & 871.3 \\
\hline
\end{tabular}


Generally, adsorbent with a higher surface area would have a higher adsorption capacity (Nahil \& Williams 2012; Pourmand et al. 2015). However, in many cases, surface area is inadequate to explain the adsorption properties of carbons; hence, the characteristic and quantity of surface functional groups present in charcoals should also be considered (Nahil \& Williams 2012; Timur et al. 2010). The most crucial and usual groups affecting the adsorption and surface characteristics of charcoals are functional groups containing oxygen that elevate the adsorption of polar species (Avgul et al. 1970).

To study the functional groups responsible for RO16 dye degradation, FTIR spectroscopy was used to compare the five different sources of charcoals used. The FTIR spectra of the charcoals showed that the peak patterns for all charcoals were close to each other, which indicated that their functional groups were also quite similar (Tsai et al. 2006) (Figure 7). The broad band at around the wavenumber of $3,396 \mathrm{~cm}^{-1}$ denoted the presence of hydroxyl groups in charcoals. All charcoals showed $\mathrm{C}-\mathrm{H}$ band around $2,926 \mathrm{~cm}^{-1}$, except for the commercial activated charcoal. The existence of $\mathrm{C}=\mathrm{O}$ group can be seen around the wavenumber at $1,687 \mathrm{~cm}^{-1}$. The $\mathrm{C}=\mathrm{C}$ stretching band appeared around $1,586 \mathrm{~cm}^{-1}$ in all spectra, except for the commercial activated charcoal, indicating the existence of aromatic rings. This can be proven by the presence of out-of-plane C-H aromatic bending vibration region (900$690 \mathrm{~cm}^{-1}$ ) (Pavia et al. 2008). The band around $1,619 \mathrm{~cm}^{-1}$ implied the presence of $\mathrm{C}=\mathrm{C}$ alkene in mangrove wood and commercial activated charcoals and this is proven by out-of-plane $=\mathrm{C}-\mathrm{H}$ bending that occurred in the range of 1000 to $650 \mathrm{~cm}^{-1}$ (Pavia et al. 2008). The absorption band around $1,193 \mathrm{~cm}^{-1}$ confirmed the presence of $\mathrm{C}-\mathrm{O}$ in all charcoals.

Surface phenomenon results in forces of binding between the adsorbent surface and molecules, atoms and ions of adsorbate are called adsorption process (Lokman 2006). All charcoal composite electrodes showed the potential to adsorb and degrade RO16 dye. The major functional groups in the charcoals (hydroxyl and carboxyl) caused the sorption properties, which helped to bind the dye (Tan et al. 1993). The presence of hydroxyl and carbonyl groups was able to form Van der Waals bonding with the RO16 molecule. The Van der Waals forces may occur

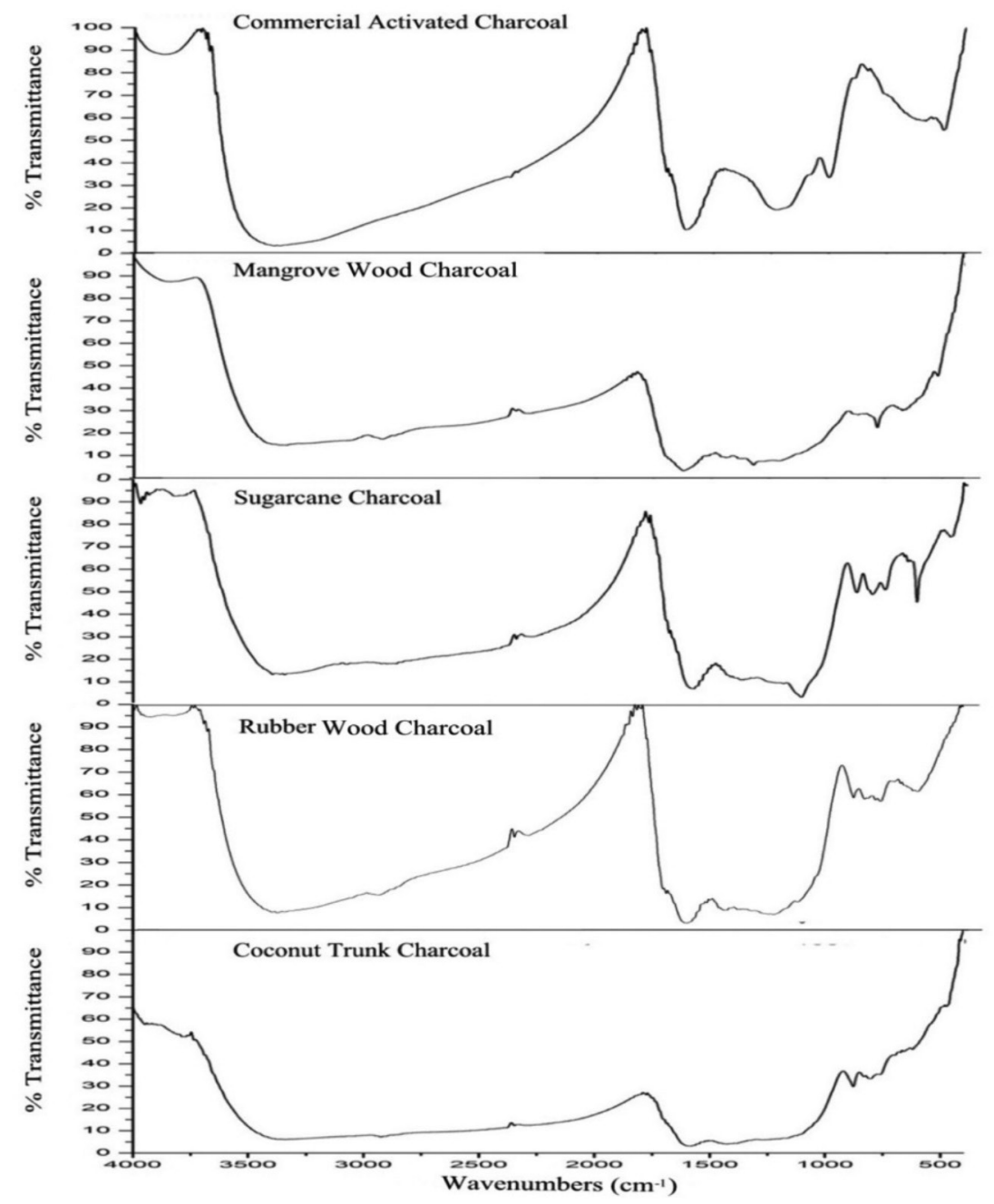

FIGURE 7. FTIR spectra of raw charcoals powder obtained from different sources 
between the azo group of the dye and the functional groups of the charcoals (alone or as electrodes) and destruct some of the dyes (Sakkayawong et al. 2005).

Other than charcoal, graphite and tin were used in the mixture of the electrode pellets at certain weight ratio. Graphite and tin are known as good electric conductors. Additionally, graphite has potential as electrocatalyst (Iqbal \& Ashiq 2007; Moore et al. 2004). The charcoal-based composite electrodes fabricated in this study had good quality as working electrode since they could degrade RO16 dye, cheap and easily prepared.

Since the FTIR spectra showed that functional groups for the charcoals were quite similar, the reason behind each electrode efficiency is still unknown. The results obtained from BET and SEM studies also showed no relation with the difference in efficiency of the electrodes. The results indicated that adsorption capacity is not the main factor affecting the electrodes capability to degrade RO16 dye molecule.

In this study, where $\mathrm{NaCl}$ was used as the supporting electrolyte, indirect oxidation played an important role in the degradation of RO16 dye molecule. Here, the dye molecule was destroyed in the bulk solution through oxidation by a strong electrochemically generated oxidant, such as hypochlorite ion and chlorine. Sodium chloride is most commonly used in textile processing industries since it is inexpensive and quite efficient (Rajkumar \& Kim 2006). The hypochlorite/chlorine was produced from chloride ion from $\mathrm{NaCl}$ by applying electrical current to the solution (Raghu et al. 2009). The oxidant was generated in situ and utilised promptly (Rajeshwar \& Ibanez 1997). The RO16 dye (pollutant) was oxidized and the hypochlorite/ chlorine was reduced back to chloride ion (Raghu et al. 2009).

The existing or the formation of hypochlorite ion in degradation of the dye molecule was confirmed by the electrolysis of $0.2 \mathrm{M} \mathrm{NaCl}$ solution alone with different sources of charcoals in charcoal-based composite electrodes for $20 \mathrm{~min}$. The UV-visible spectra obtained showed a single maximum peak absorption of hypochlorite ion at $291 \mathrm{~nm}$ (Figure 8). Electrode contained charcoal that is originated from coconut trunk gave the highest intensity of hypochlorite ion after $20 \mathrm{~min}$, followed by rubber wood, sugarcane, mangrove wood and commercial activated charcoal.

The production of hypochlorite ion is in agreement with the decolourisation rate demonstrated by all electrodes, therefore, verifying that the production of hypochlorite ion was the main aspect influencing the electrode effectiveness in this research. Therefore, based on this study the formation of hypochlorite ion played the most important role rather than the adsorption process in the degradation of RO16 dye molecule. The reactions are assumed to happen in the bulk solution (Raghu et al. 2009; Rajkumar \& Kim 2006).

Anode:

Main reaction: $2 \mathrm{Cl}^{-} \rightarrow \mathrm{Cl}_{2}+2 \mathrm{e}^{-}$

$$
\text { Side reaction: } 4 \mathrm{OH}^{-} \rightarrow \mathrm{O}_{2}+2 \mathrm{H}_{2} \mathrm{O}+4 \mathrm{e}^{-}
$$

Bulk solution:

$$
\begin{aligned}
& \mathrm{Cl}_{2}+\mathrm{H}_{2} \mathrm{O} \rightarrow \mathrm{HOCl}+\mathrm{H}^{+}+\mathrm{Cl}^{-} \\
& \mathrm{HOCl} \rightarrow \mathrm{H}^{+}+\mathrm{OCl}^{-} \\
& \text {Dye }+\mathrm{OCl}^{-} \rightarrow \mathrm{CO}_{2}+\mathrm{H}_{2} \mathrm{O}+\mathrm{Cl}^{-}+\text {Products }
\end{aligned}
$$

Cathode:

$$
2 \mathrm{H}_{2} \mathrm{O}+2 \mathrm{e}^{-} \rightarrow \mathrm{H}_{2}+2 \mathrm{OH}^{-}
$$

The enhancement in removal efficiency of the dye was attributable to the increment in chloride ions in the electrolyte. The complete breakdown of RO16 dye was achieved through the involvement of active chlorine, namely hypochlorous acid, chlorine, and hypochlorite ion. These oxidants react with the dye molecules and finally lead to their complete conversion to carbon dioxide, water and other smaller molecules (Martinez \& Ferro 2006).

Based on results obtained, as summarized in Figure 4, Table 2 and Figure 8, it is confirmed that the oxidation of RO16 dye molecule mostly occurred in the bulk solution. The composite electrode functions as a hypochlorite ion generator only. Adsorption process on the electrode surface did not play any significant role in decolourisation of the dye.

Energy consumption, current efficiency and operating cost were also taken into consideration as one of the objectives to fabricate low cost electrodes (Table 3 ). The energy consumptions and current efficiencies were measured per $g$ of COD removed. The energy consumptions and current efficiencies for all electrodes fabricated were compared, and from the results obtained, it can be seen that there was a connection between energy consumption and current efficiency. The application of electrode with high current efficiency reduced energy usage. Current efficiency and energy consumption of commercially available charcoal-based composite electrode are, respectively, the highest and the lowest, even though its capability to

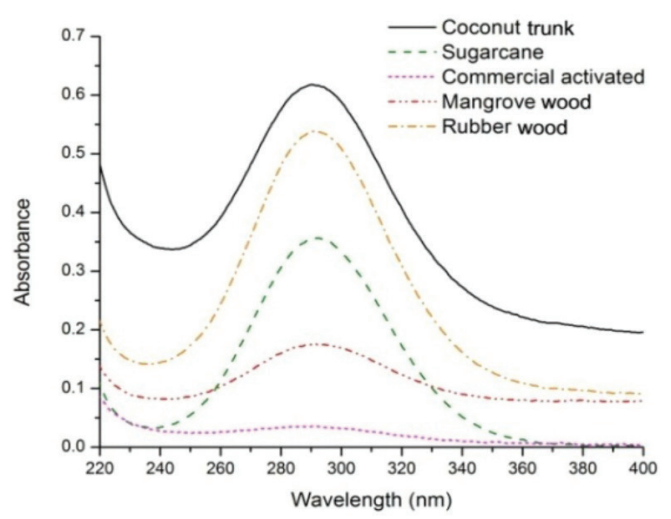

FIGURE 8. UV-visible spectra for the formation of hypochlorite ion using composite electrodes originated from different sources of charcoals 
TABLE 3. Cost, energy consumption and current efficiency

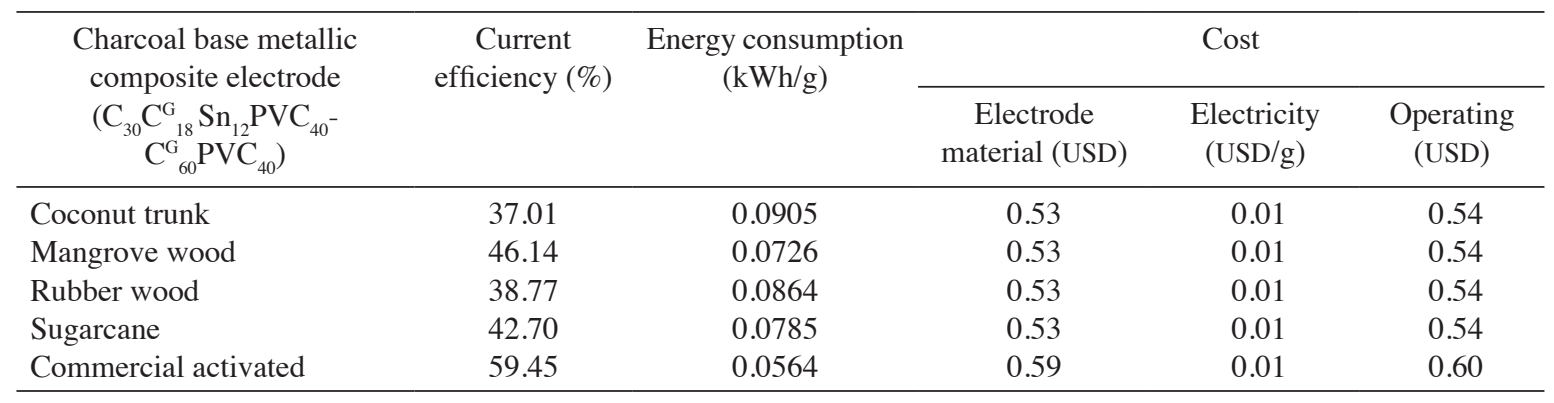

Current efficiency and energy consumption were calculated based on $60 \mathrm{~min}$ electrolysis. Current electricity rate is $0.01 \mathrm{USD} / \mathrm{kWh}$

degrade RO16 dye is the lowest than other electrodes. The objective of this research was achieved since the range of operating cost for all the fabricated electrodes was only within USD0.54 to USD0.60.

There are a number of research were done to study the degradation of reactive dyes by using electrochemical method (Neti \& Misra 2012; Wu et al. 2008; Xiong et al. 2001; Xu et al. 2008). The use of coconut trunk charcoal composite electrode in the degradation of dyes in this study showed good performance as compared to the previous studies. In this study, about $98.5 \%$ of RO16 dyes (200 mg/L) was achieved in $20 \mathrm{~min}$, while Neti and Misra (2012) can degrade about $85 \%$ from $50 \mathrm{mg} / \mathrm{L}$ of RB4 solution in $6 \mathrm{~h}$.

\section{CONCLUSION}

The comparative study of five different charcoal sources in the fabrication of charcoal composite electrodes in the decolourisation of RO16 dye was successfully performed, in which the discolouration rates of charcoals were in the following order: coconut trunk $>$ rubber wood $>$ sugarcane $>$ mangrove wood $>$ commercial activated. The formation of hypochlorite ion was discovered as the main factor that influence the results. The surface area and the presence of carbonyl and hydroxyl groups in the charcoals increased the adsorption capacity of charcoals, and thus contributing to the efficiency of dye removal. From the results obtained, it can see that there is no connection between colour and COD removal. The results concluded that all charcoal composite electrodes had good potential in decolourising RO16 textile dye. The oxidation process of RO16 dye molecule mostly occurred in the bulk solution and not on the electrode surface. The composite electrode functions only as a hypochlorite ion generator. Adsorption process on the electrode surface did not play any significant role in decolourisation of the dye. This research is crucial since it proved that agricultural wastes, as the main element in charcoal-based electrode, can treat water pollution caused by textile industries.

\section{ACKNOWLEDGEMENTS}

The authors are grateful to the School of Chemical Sciences and Food Technology and Centre for Water Research and Analysis (ALIR), Faculty of Science and Technology, Universiti Kebangsaan Malaysia for the instrumental facilities and the FRGS/2/2013/SG01/UKM/01/1 grant for financial support.

\section{REFERENCES}

Achaw, O.W. 2012. A study of the porosity of activated carbons using the scanning electron microscope. Croatia: INTECH Open Access Publisher. DOI: 10.5772/36337.

Abdollahi, M. \& Hosseini, A. 2014. Encyclopedia of Toxicology. Oxford: Academic Press.

Ahmedna, M., Marshall, W. \& Rao, R. 2000. Production of granular activated carbons from select agricultural byproducts and evaluation of their physical, chemical and adsorption properties. Bioresource Technology 71: 113-123.

Alvares, A., Diaper, C. \& Parsons, S. 2001. Partial oxidation by ozone to remove recalcitrance from wastewaters - A review. Environmental Technology 22: 409-427.

Andrade, L.S., Tasso, T.T., Da Silva, D.L., Rocha-Filho, R.C., Bocchi, N. \& Biaggio, S.R. 2009. On the performances of lead dioxide and boron-doped diamond electrodes in the anodic oxidation of simulated wastewater containing the Reactive Orange 16 dye. Electrochimica Acta 54: 2024-2030.

Avgul, N., Kiselev, A. \& Walker Jr., P. 1970. Chemistry and Physics of Carbon. New York: Dekker.

Bauer, C., Jacques, P. \& Kalt, A. 2001. Photo-oxidation of an azo dye induced by visible light incident on the surface of $\mathrm{TiO}_{2}$. Journal of Photochemistry and Photobiology A: Chemistry 140: 87-92.

Chatzisymeon, E., Xekoukoulotakis, N.P., Coz, A., Kalogerakis, N. \& Mantzavinos, D. 2006. Electrochemical treatment of textile dyes and dyehouse effluents. Journal of Hazardous Materials 137: 998-1007.

Chen, C.Y. 2009. Photocatalytic degradation of azo dye Reactive Orange 16 by $\mathrm{TiO}_{2}$. Water, Air, and Soil Pollution 202: 335342.

Chen, G. 2004. Electrochemical technologies in wastewater treatment. Separation and Purification Technology 38: 11-41.

Chung, K.T. \& Stevens, S.E. 1993. Degradation azo dyes by environmental microorganisms and helminths. Environmental Toxicology and Chemistry 12: 2121-2132.

Doble, M. \& Kumar, A. 2005. Biotreatment of Industrial Effluents. United Kingdom: Butterworth-Heinemann.

Fernandes, A., Morão, A., Magrinho, M., Lopes, A. \& Gonçalves, I. 2004. Electrochemical degradation of C.I. Acid Orange 7. Dyes and Pigments 61: 287-296. 
Hach. 2004. DR/2400 Spectrophotometer Procedure Manual. USA: Hach Company.

Iqbal, M.J. \& Ashiq, M.N. 2007. Adsorption of dyes from aqueous solutions on activated charcoal. Journal of Hazardous Materials 139: 57-66.

Kalderis, D., Koutoulakis, D., Paraskeva, P., Diamadopoulos, E., Otal, E., Valle, J.O.D. \& Fernández-Pereira, C. 2008. Adsorption of polluting substances on activated carbons prepared from rice husk and sugarcane bagasse. Chemical Engineering Journal 144: 42-50.

Karthick, S., Kwon, S.J., Lee, H.S., Muralidhar, S., Saraswathy, V. \& Natarajan, N. 2017. Fabrication and evaluation of a highly durable and reliable chloride monitoring sensor for civil infrastructure. Royal Society of Chemistry Advances 7: 31252-31263.

Lalhruaitluanga, H., Prasad, M.N.V. \& Radha, K. 2011. Potential of chemically activated and raw charcoals of Melocanna baccifera for removal of $\mathrm{Ni}(\mathrm{II})$ and $\mathrm{Zn}(\mathrm{II})$ from aqueous solutions. Desalination 271: 301-308.

Lee, J.W., Choi, S.P., Thiruvenkatachari, R., Shim, W.G. \& Moon, H. 2006. Evaluation of the performance of adsorption and coagulation processes for the maximum removal of reactive dyes. Dyes and Pigments 69: 196-203.

Liakou, S., Pavlou, S. \& Lyberatos, G. 1997. Ozonation of azo dyes. Water Science and Technology 35: 279-286.

Lokman, F. 2006. Dye removal from simulated wastewater by using empty fruit bunch as an adsorption agent. Thesis $\mathrm{PhD}$, Universiti Malaysia Pahang (Unpublished).

Maljaei, A., Arami, M. \& Mahmoodi, N.M. 2009. Decolorization and aromatic ring degradation of colored textile wastewater using indirect electrochemical oxidation method. Desalination 249: 1074-1078.

Martinez-Huitle, C.A. \& Ferro, S. 2006. Electrochemical oxidation of organic pollutants for the wastewater treatment: Direct and indirect processes. Chemical Society Reviews 35: 1324-1340.

Migliorini, F.L., Braga, N.A., Alves, S.A., Lanza, M.R.V., Baldan, M.R. \& Ferreira, N.G. 2011. Anodic oxidation of wastewater containing the Reactive Orange 16 dye using heavily borondoped diamond electrodes. Journal of Hazardous Materials 192: 1683-1689.

Mohan, N., Balasubramanian, N. \& Basha, C.A. 2007. Electrochemical oxidation of textile wastewater and its reuse. Journal of Hazardous Materials 147: 644-651.

Moore, R.R., Banks, C.E. \& Compton, R.G. 2004. Basal plane pyrolytic graphite modified electrodes: Comparison of carbon nanotubes and graphite powder as electrocatalysts. Analytical Chemistry 76: 2677-2682.

Nahil, M.A. \& Williams, P.T. 2012. Surface chemistry and porosity of nitrogen-containing activated carbons produced from acrylic textile waste. Chemical Engineering Journal 184: 228-237.

Neti, N.R. \& Misra, R. 2012. Efficient degradation of Reactive Blue 4 in carbon bed electrochemical reactor. Chemical Engineering Journal 184: 23-32.

Nigam, P., Banat, I.M., Singh, D. \& Marchant, R. 1996. Microbial process for the decolorization of textile effluent containing azo, diazo and reactive dyes. Process Biochemistry 31: 435-442.

Öğütveren, Ü.B. \& Koparal, S. 1994. Color removal from textile effluents by electrochemical destruction. Journal of Environmental Science and Health. Part A: Environmental Science and Engineering and Toxicology 29: 1-16.
Paszczynski, A. \& Crawford, R.L. 1995. Potential for bioremediation of xenobiotic compounds by the whiterot fungus Phanerochaete chrysosporium. Biotechnology Progress 11: 368-379.

Parsa, J.B., Rezaei, M. \& Soleymani, A.R. 2009. Electrochemical oxidation of an azo dye in aqueous media investigation of operational parameters and kinetics. Journal of Hazardous Materials 168: 997-1003.

Pavia, D., Lampman, G., Kriz, G. \& Vyvyan, J. 2008. Introduction to Spectroscopy. USA: Cengage Learning.

Pelegrini, R., Peralta-Zamora, P., De Andrade, A.R., Reyes, J. \& Durán, N. 1999. Electrochemically assisted photocatalytic degradation of reactive dyes. Applied Catalysis B: Environmental 22: 83-90.

Pourmand, S., Abdouss, M. \& Rashidi, A. 2015. Preparation of nanoporous graphene via nanoporous zinc oxide and its application as a nanoadsorbent for benzene, toluene and xylenes removal. International Journal of Environmental Research 9: 1269-1276.

Raghu, S., Lee, C.W., Chellammal, S., Palanichamy, S. \& Basha, C.A. 2009. Evaluation of electrochemical oxidation techniques for degradation of dye effluents - A comparative approach. Journal of Hazardous Materials 171: 748-754.

Rajeshwar, K. \& Ibanez, J.G. 1997. Fundamentals and Applications in Pollution Abatement. San Diego: Academic Press.

Rajkumar, D. \& Kim, J.G. 2006. Oxidation of various reactive dyes with in situ electro-generated active chlorine for textile dyeing industry wastewater treatment. Journal of Hazardous Materials 136: 203-212.

Rashidi, H.R., Sulaiman, N.M., Hashim, N.A. \& Che Hassan, C.R. 2012. Synthetic batik wastewater pre-treatment progress by using physical treatment. Advanced Materials Research 627: 394-398.

Robinson, T., McMullan, G., Marchant, R. \& Nigam, P. 2001. Remediation of dyes in textile effluent: A critical review on current treatment technologies with a proposed alternative. Bioresource Technology 77: 247-255.

Riyanto, Salimon, J. \& Othman, M.R. 2007. Perbandingan hasil pengoksidaan elektrokimia etanol dalam larutan alkali yang menggunakan elektrod platinumpolivinilklorida (Pt-PVC) dan kepingan logam Pt. Sains Malaysiana 36(2): 175-181.

Puvaneswari, N., Muthukrishnan, J. \& Gunasekaran, P. 2006. Toxicity assessment and microbial degradation of azo dyes. Indian Journal of Experimental Biology 44: 618-626.

Salehin, S., Aburizaiza, A. \& Barakat, M. 2015. Recycling of residual oil fly ash: Synthesis and characterization of activated carbon by physical activation methods for heavy metals adsorption. International Journal of Environmental Research 9: 1201-1210.

Sakkayawong, N., Thiravetyan, P. \& Nakbanpote, W. 2005. Adsorption mechanism of synthetic reactive dye wastewater by chitosan. Journal of Colloid and Interface Science 286: 36-42.

Saxe, J.P., Lubenow, B.L., Chiu, P.C., Huang, C.P. \& Cha, D.K. 2006. Enhanced biodegradation of azo dyes using an integrated elemental iron-activated sludge system: II. Effects of physical-chemical parameters. Water Environment Research 78: 26-30.

Śíma, J. \& Hasal, P. 2013. Photocatalytic degradation of textile dyes in a $\mathrm{TiO}_{2} / \mathrm{UV}$ system. Chemical Engineering Transactions 32: 79-84. 
Sharma, S., Sharma, S., Pathak, S. \& Sharma, K.P. 2003. Toxicity of the azo dye methyl red to the organisms in microcosms, with special reference to the guppy (Poecilia reticulata Peters). Bulletin of Environmental Contamination and Toxicology 70: 753-760.

Tan, W., Ooi, S. \& Lee, C. 1993. Removal of chromium (VI) from solution by coconut husk and palm pressed fibres. Environmental Technology 14: 277-282.

Tizaoui, C. \& Grima, N. 2011. Kinetics of the ozone oxidation of Reactive Orange 16 azo-dye in aqueous solution. Chemical Engineering Journal 173: 463-473.

Timur, S., Kantarli, I.C., Onenc, S. \& Yanik, J. 2010. Characterization and application of activated carbon produced from oak cups pulp. Journal of Analytical and Applied Pyrolysis 89: 129-136.

Tsai, W.T., Lee, M.K. \& Chang, Y.M. 2006. Fast pyrolysis of rice straw, sugarcane bagasse and coconut shell in an inductionheating reactor. Journal of Analytical and Applied Pyrolysis 76: $230-237$

Wang, S. \& Li, H. 2007. Kinetic modelling and mechanism of dye adsorption on unburned carbon. Dyes and Pigments 72 : 308-314.

Willmott, N., Guthrie, J. \& Nelson, G. 1998. The biotechnology approach to colour removal from textile effluent. Journal of the Society of Dyers and Colourists 114: 38-41.

Wu, X., Yang, X., Wu, D. \& Fu, R. 2008. Feasibility study of using carbon aerogel as particle electrodes for decoloration of RBRX dye solution in a three-dimensional electrode reactor. Chemical Engineering Journal 138: 47-54.

Xiong, Y.A., Strunk, P.J., Xia, H., Zhu, X. \& Karlsson, H.T. 2001. Treatment of dye wastewater containing acid orange II using a cell with three-phase three-dimensional electrode. Water Research 35: 4226-4230.

Xu, L., Zhao, H., Shi, S., Zhang, G. \& Ni, J. 2008. Electrolytic treatment of C.I. Acid Orange 7 in aqueous solution using a three-dimensional electrode reactor. Dyes and Pigments 77: $158-164$.

Xu, Y., Lebrun, R.E., Gallo, P.J. \& Blond, P. 1999. Treatment of textile dye plant effluent by nanofiltration membrane. Separation Science and Technology 34: 2501-2519.
Zakaria, Z., Nordin, N., Hasan, S.Z., Baharuddin, N.A., Jumaah, M.A. \& Othman, M.R. 2015. Decolorization of Reactive Orange 16 dye using fabricated charcoal base metallic composite electrode. Malaysian Journal of Analytical Sciences 19: 493-502.

Zollinger, H. 2003. Color Chemistry: Synthesis, Properties and Applications of Organic Dyes and Pigments. 3rd ed. Weinheim: Wiley-VCH.

Zuhailie Zakaria, Mohamed Rozali Othman \& Wan Yaacob Wan Ahmad

School of Chemical Science and Food Technology

Faculty of Science and Technology

Universiti Kebangsaan Malaysia

43600 UKM Bangi, Selangor Darul Ehsan

Malaysia

Zuhailie Zakaria

Production Audit Department

Syarikat Air Terengganu Sdn. Bhd.

20200 Kuala Terengganu, Terengganu Darul Iman

Malaysia

Siti Zubaidah Hasan*

Research Centre for Sustainable Development Technology

Faculty of Engineering and Built Environment

Universiti Kebangsaan Malaysia

43600 UKM Bangi, Selangor Darul Ehsan

Malaysia

*Corresponding author; email: p88955@siswa.ukm.edu.my

Received: 19 September 2018

Accepted: 23 January 2019 